\title{
MINING POLICY, LOCAL ACTORS, AND LOCAL ELECTION (Empirical Evidence from South Kalimantan Province, Indonesia)
}

\author{
Muhammad Uhaib As'ad; Murdiansyah Herman \\ Faculty of Social and Political Sciences at Islamic University of Kalimantan \\ uhaibm@yahoo.com; murdiansyahuniska@gmail.com
}

\begin{abstract}
The purpose of this paper to describes the involvement of coal mining bosses in local elections and their impact on coal mine management policies and it's impact on local political dynamics in South Kalimantran. South Kalimantan is known as an regency that has the potential of coal mining resources has made as an instrument of conspiracy or political transactional arena among actors to control political power through of regional head elections arena. A number of coal mining bosses in a number of regional head elections in South Kalimantan are involved as a sponsorship of political funds for certain candidates in local elections. The involvement of a number of coal mining bosses, economically and politically has made the chosen ruler a puppet of the capitalists has controlled government, especially in natural resource management policies The data collection in this study used in-depth interviews with local actors involved in the elections, such as coal mine bosses, local bureaucrats, community leaders, NGO activists, mass media and other interest groups.Thi study used a number of literature reviews, other research results, as well as journals that have relevance to the study. The implication of this research result can be explained that the involvement of a number of mining entrepreneurs in the elections has struck on government policy especially in mining management. The strengthening of the business and political conspiracy network between rulers and businessman in patron-client pattern and business cronies. In addition, the mine entrepreneurs have repositioned themselves in power networks as patron client.
\end{abstract}

Keywords: Coal Mining, Local Election, Local Actors, Conspiracy, South Kalimantan

\section{Introduction}

This paper will describe the network patterns of the mine predators. One of the arenas of building a conspiracy network of mining predators is at the time of the regional head election. Heinvolvement of mine predators behind democratic capitalization,acting as a political broker or supporting fiancier, as well as a strategyof building patronage with potential rulers area. He capitalization ofdemocracy, the local political landscape in South Kalimantan Province,mining issues always color political marketing among the actors whofought in the democratic event (election).

The involvement of mining bosses in elections as a supplier of funds to build patronage with local authorities who succeeded in disaggregating is in order to expand the business network while collaborating with local authorities. The involvement of a number of entrepreneurs as funders is difficult to avoid, because between entrepreneurs and potential rulers alike have an interest. It is not even possible that funders play on two legs to fund the local ruling candidates. The issue of natural resources becomes a hostage and an arena of economic and political interest struggles among local actors. It is not surprising, therefore, 
that the political scene in South Kalimantan is controlled by the strength of capital or dominated by politicians with mining entrepreneurs (As'ad, 2016).

In the demoratic capitalization and political behaviour pragmatism era, politicians with entrepreneurial backgrounds will have opportunity win of political power through political transactional. Therefore, only large capital owners who have a certain opportunity or person who has a patronage relationship with capital domination can appear as a fighter in the elections. Meanwhile, for people who do not have capital, although they have integrity, social capacity and political capacity, but do not have the political belief to win the struggle for political power in the arena of elections. This condition became phenomenon in political landscape in some elections in South Kalimantan (Hidayat, 2001).

The dynamics of local politics in South Kalimantan is always the network between mine activity and politics is inseparably the attraction of a breath produced by local actors. In addition, the position of political parties in South Kalimantan is more controlled by mining entrepreneurs. The political elites having a strategic position in the party will automatically have a political bargaining position in the political landscape process, especially in the elections. Coal mining entrepreneurs have made political party institutions a strategy of building economic and political power relations between local and central actors (As'ad, 2017).

As a result every individual is trying to become a free rider who utilizes natural resources A resource that benefits a group of people, but which provides diminished benefits toeveryone if each individual pursues his or her own self-interest. The value of a common pool resource can be reduced through overuse because the supply of the resource is notunlimited, and using more than can be replenished can result in scarcity. Natural resources are only beneficial to a particular group or a few people. But this resource is not always eternal because the number is only limited. If each person or group only prioritizes its own interests then what will happen is the seizure of resources and will lead to scarcity and generate reduction of benefits for each person or group. Because in this competition the resources must be divided into the respective actors.

\section{Theory and Research Empirically: South Kalimantan Provinsi as a Setting}

The rich resources of the regions have yet to lead to improved living stadards or welfare for the population of the province. On the contrary, they have led to marginalization of local people from their traditional livelihoods, and massive environmental destruction.. If these resources were better managed in accordance with good governance principles, they should be able to produce improved welfare in terms of education, health and infrastructure development (Fatah, 2008).

This phenomenon has become arguably the most striking feature of local politics in South Kalimantan in the era since the reformasi process and decentraliszation policies began in Indonesia more than a decade ago (Brilantes, 2004). Meanwhile, the local community faces a situation of highly assymetrical power relations, lacking the capacity or the political access to become involved in the management of the natural resources sector. As a result, there are often episodes of community resistance to mining operations, including in the form of demonstrations, or most recently in 2012 of a blockade of access to river transportation for the mines. These forms of resistance are motivated by a sense of injustice on the part of local 
people, both concerning their relations with the companies and the failure of corporate responsiblity, as well concerning the division of royalties between Jakarta and the regions.

Of the 13 districts (kabupaten) and muncipalities (kota) in South Kalimantan, more than half produce coal. But infrascture and economic development, as well as social welfare are lagging, as reflected in the provinces's HDI ranking of 26 out of the 34 provinces of Indonesia. It turns out that the rich natural resources of the province have not provided a significant contribution to the local community. In fact, it can be said that the province is experiencing a resource curse whereby, resource wealth promotes the ascendance of the predatory state over the developmental state, either by actively encouraging the former through corruption related to resource rents, or by undermining the latter when revenue flows associated with resource extraction reduce the efficiency of policy and administration.

All of this is happening as a result of the failure of good corporate governance. The key principles of good governance including 1) accountability 2) transparency 3) participation 4) law enforcement. To take one of these principles as an example, transparency, there is very limited public knowledge about the annual earnings of the various mines. Indeed, even officials of the provincial office of the Department of Mining say that they do not know the exact production figures for the province on an annual basis, both because they believe many of the reports they receive from the districts are invalid, and because they are only able to make a rough estimate of 1.2 million tonnes per year of production for those large mines whose licenses are issued by the national agency (interview with provincial head of the Mining Agency, December 2017).

This situation not only reflects poor coordination between the different levels of government, it also makes it impossible for provincial officials to know whether royalties are being paid at rates in accordance with prevailing regulations to the various levels of government. For instance, 2.7 trillion rupiah per year is paid each year to the province from royalties raised from the mines whose licenses are issued by the central government in Jakarta, with part of that income then redistributed to the districts where the mines are located. After political lobbying by the provincial government in Jakarta, this amount was increased to 2.7 trillion rupiah in 2013 (source: interview with the head of Commission III of the provincial legislature, February 2017), in part as a result to the political controversy and protests that had been building in the province. Despite the increase, the various revenue flows involved are still entirely lacking in transparency: provincial officials know neither what the companies profits are or what share Jakarta takes.

The local autonomy has opened the political opportunity structure for local elites to use government insitutions and regulations to extract natural resources for their own benefits. In doing so, they typically argue that their goal is to increase local revenues (Pendapatan Asli Daerah, PAD) in order to fund regional development projects. For instance, in the district of Tanah Bumbu, more than $40 \%$ of PAD is obtained from the mining industry. However, this increase of local revenues has not produced significantly improved infrastructure or economic conditions at the local level. The district of Tanah Bumbu provides a good example of the negative effects of the mining industry on local governance.

With 251 mine licenses issued by the bupati (district head), the district is one of the highest intensity mining districts in the province. The industry has produced not only formal revenues for the local government, but also informal revenue streams for individual officials 
in the local government and the security apparatus. For each barge that leaves the district packed with coal (and there is an average monthly frequency of up to 80 barges passing down the Barito river to their rendevous points with cargo ships at sea), payments of hundreds of millions of rupiah are made by the mining companies to local officials.

These payments, which the companies budget as 'tactical funds', are then divided among local officials such as subdistrict police chiefs, subdistrict mlitary chiefs, subdistrict civil government heads, harbourmasters, marine police commanders, navy officers and the relevant police, army and civilian government officials at the district level, with it being widely undestood that payments are made to provincial and central government officials as well. The amounts paid to the individuals vary according to their seniority and function. For example, it has been estimated that the subdistrict head in Setui can receive "hot money" of approximately 40 million rupiah (approximately \$4,200), more than ten times his basic wage. Other officials seek funds from the mining industry in other ways, for example by supplying fuel to the companies, by acting as brokers between them and buyers, or by supplying security services at mining sites. As a result of such practies, over the last decade many officials in the district have been able to enrich themsleves.

The critical point in the regulation of mining - and the core site of political transactions between political and business actors - is in the issuing of mining company Licenses (Izin Usaha Pertambangan, IUP). The national ministry of minerals and resources is responsible for issuing licensese for mines that cross provincial boundaries or cross several district boundaries and has issued 27 such licenses in South Kalimantan (one example is the license for PT Adaro in the districts of Tabalong and Balangan, PT Arutmin Indonesia in Kota Baru and Tanah Bumbu, owned by the famous Indonesian mining magnate and politician, Aburizal Bakrie). Over 600 licenses have been issued by the various bupati (district heads), with the largest number being issued in the district of Tanah Bumbu with over 200 .

The environmental organisaton has identified systematic corruption around the issuing of IUP. For example, many IUP are issued without the prior issuance of a special license for the use of protected forest land by the regional office of the Forestry Ministry, or prior to the carrying out of an environmental impact assessment. Another chronic problem is the issuing of mining licenses in areas that are designated for other purposes in regional regulations on spatial planning, such community farming, oil palm plantations, or forestry operations. Indeed, the combined total of land allocated for mining, forestry and plantation in the province amounts to 3.1 million hectares, not far short of the total land area of South Kalimantan, 3.7 million hectares.

These licenses are typically issued in a way that is highly politicized. Recipients are very often those who have personal connections with the district head. They may be family members (for example, more than fifty of the 200 in Tanah Bumbu are held by relatives of Zairullah Azhar, former head of regency Tanah Bumbu). Recipients are often also members of the so-called "success teams" that are formed to support and fund the election campaigns of district head candidates. The transaction is typically simple: in exchange for funding for the campaign, the donor is rewarded with a mining license, and from this arrangement arises ongoing enmeshment of political and business interests in the district concerned. Political office is effectively captured by the mining boss. 
One famous example in South Kalimantan is the case of Zairullah Azhar himself. $\mathrm{H}$ Samsuddin (usually known as Haji Isam) was already a wealthy businessman (mostly with timber interests before the election of Zairullah. After he (along with several other businessmen) sponsored Zairullah's election his mining operations expanded dramatically in the district. He later sponsored Zairullah's attempt to run as governor in the 2010 gubernatorial elections, at great cost (Zairullah lost to Rudy Ariffin, whose main sponsor was Haji Ijai, another famous local coal mining magnate based in Binuang in the district of Tapin). Zairullah's successor as district head, Madani H. Maming was himself previously a coal miner. His wealth originated with his father, who was a village head in an area rich in coal. Previous to becoming district head, he was a member of the district legislature, a strategic position from which he could influence local economic policy. He defeated the elder brother of Zairullah in the 2011 elections in the district, in what was effectively a contest between rival mining regimes.

For example, four years ago a massive flood occurred in Tanah Bumbu, destroying a number of major bridges and causing loss of life, as a result of deforestation linked to the mining industry (this flooding was part of a wider wave of floods, with 21 floods recorded in 2009, inundating over 15.000 hectares of rice fields, and affecting 11 of the province's 13 districts; sources, WALHI, 2011). Another serious problem in the district is the unregulated nature of mining waste disposal which has caused widespread water pollution with heavy metals and causing skin ailments, among other problems. Several of the mines in the district are located very close to villages. For example, in the sub-district of Satui mining takes place along the side of a main road; a local cemetery has even been dug up to make way for the excavations. Satui has become akin to a mining town in the midst of what was once a quiet rural district. The infrastructure is reasonably advanced in this town - e.g. education and health centers - but it is one of the very few places in South Kalimantan to experience such benefits, while most of the villages in the district concerned have experienced significant economic marginalization.

\section{Discussion and Conclusion}

There are three critical domains in governance: 1) government 2) the corporate sector and 3) civil society. In the governance of the mining sector in South Kalimantan, the relations between these three domains is imbalanced. The government is largely captured by the corporate sector and is unable to play the control function role it should be able to exercise with regards to the private sector. Civil society is marginalized in the governance process though local NGOs, and the mass media are significant local actors - they have over the last decade been little not involved in the process of formulating and implementing management over the coal sector. However, in recent times, especially since 2012, the beginnings of a change of public mood have been visible. The widespread environmental and social damage caused by mining has been gaining increasing publicity and has led to attempts to begin to introduce regulations to deal with some of the worst aspects of the industry.

In 2012-13, the provincial executive government and DPRD (provincial legislature) were engaged in a long process of negotiation to produce a new local regulation requiring coal companies to rehabilitate land after the closure of their mines. This is widely agreed as being an urgent need in the province, with many local companies having abandoned their 
mines without cleaning up the sites, leaving huge holes in the ground that form into lakes, ponds and rivers. The result is ongoing environmental damage, localized flooding, malaria and other water-borne diseases, as well as other negative effects. The coal of reclamation is to rehabilitate these sites to return them to productive use for local communities, in the form of farm land.

As a result of public pressure on the issue, in 2012 a group of legislators in the DPRD's Commission III (the commission responsible for mining policy) established a special committee (panitia khusus pansus) to draft a bill dealing with the matter. Public hearings were arranged, with local academics, experts, NGO activists and the mass media invited to present their input into the drafting process. This was a very costly process, with the DPRD members involved three times going on study visits to other mining provinces in Indonesia (for example, they visited the PT Bukit Asam operations in South Sumatra, November 2012).

However, as time passed, implementation became less effective, with mining trucks increasingly using these roads, especially at night time, facilitated by paying illegal fees to officials in the monitoring posts that were set up along the roads to enforce the new rules. The roads which had been repaired, rapidly became damaged once again by the passage of heavy mining trucks. With such experiences behind them, many people in South Kalimantan now believe that the politically connected mining companies will be able to avoid obeying the letter of the new reclamation regulation. In conditions in which illegality has become a norm of corporate behavior, it is unlikely that improved regulations will alone improve the situation.

The business and political relationships in the mining industry in South Kalimantan Province are inseparable as two sides of the coin. The issue of the mining has always been political marketing as a strategy to make bergaining position or networks business and political patronage. This can not be avoided because after the Soeharto's government, the national political dynamics became more liberal, pragmatic, and the more capitalistic democratic process which of course required a high cost. Therefore, at present almost all the regional authorities in South Kalimantan Province are people who have a background of entrepreneurs, especially coal mine businessmen. They have the capital or the power of money to finance a transactional, capitalistic democracy. Similarly, almost the heads of political parties or administrators of political parties are entrepreneurs or backgrounds of coal mining businessmen. Usually the rulers run for regional ruling candidates or sponsor political funds for candidates who fight in local elections (As'ad, 2016 2017, Aspinall and As'ad, 2015, Aspinall and As'ad, 2016).

As the main leading argument of this paper that rich of natural resources, particularly in the coal mining sector have not been directly proportional to the improvement of economic and social justice for communities despite the decades-long exploitation of coal mines. The policy of decentralization has created opportunities for local actors and mine predators to utilize decentralized mine resource management by building conspiracy networks and local officials or political elites who have positions in local government and legislative members as well as with security forces such as police and soldiers.

As for the networks pattern of conspiracy between local officials and mining entrepreneurs through the expenditure of mining business permits: First, licensing issued 
without consideration of the spatial layout or the carrying capacity of the natural environment causing many conflicts between citizens with mining companies and massive clearance of protected forest areas. Second, usually the issuing permit is issued ahead of the election of regional head (regent and gobernur) as a strategy to strengthen the mutually beneficial network of business patronage and transactional politics. Third, the overlapping of permits that reach the thousands is allowed to last protracted and potentially become a bargaining event between the ruler and the entrepreneur. Fourth, the abuses of lawlessness in major cases of public interest that resulted in state losses arising from corruption and mafia practices in the mining sector.

In the mining business license expenditure requires a lot of funds. This is an opportunity to get funds for local officials authorized to issue mining permits. The province of South Kalimantan is well known with many mining permits issued by several local heads. Such practices have long been taking place, especially since decentralization and regional autonomy have been implemented since local governments have wide-ranging regulation policies that are barely controlled by the public because of their under cover nature. The management of natural resources that has been going on for so long is managed in mafia and sermpangan ways does not put forward the principles of accountability, transparency, and justice. Not implementing good governance coal mining practices. But the opposite is seen is the management of bad governance coal mining practices that do not give a sense of justice for the public. The practice of corruption, mining mafia, and abuse of power has led to victim of policy for local communities and environmental degradation and has become a vicious circle that is difficult to disentangle because there is no political will from stakeholders to implement transparent and accountable mining policies, but what happens is the conspiracy and greed of local (As'ad, 2015).

\section{References}

As'ad. M.U. (2015). Mining and Local Election: Understanding the Dynamic of Local Politic in South Kalimantan, Banjarmasin: Faculty of Social and Political Sciences Press.

As'ad. M.U. (2016), Mining and Political Business: Conspiracy of Local Actors in Head of Local Elections, Yogyakarta: Genta Publishing.

As'ad. M.U. (2017), Mining Exploitation Policy and Poverty of Local Communities, Journal of Political Sciences and Public Affairs, December, 12

Aspinall, E. (2014). When brokers betray: Social networks adn electoral politics in Indonesia. Critical Asian Studies 46 (4): 545-570.

Aspinall, E., \& As'ad. M.U. (2015). The Patronase Patchwork:Village Brokerage Networks and the Power of the State in an Indonesian Election. Bijdragen Tot De Taal, Land-EN Volkenkunde 171 (165-195.

Aspinall, E., \& As'ad. M.U (2016). Understanding Family Politics: Success and Failures of Political Dynasties in Regioanal Indonesia. South East Asia Research, 1-16, SAGE

Brilantes Jr., A, (2004), Decentralizition Imperatives, Lessons from Some Countries, Journal of International Cooperation Studies, Vo. 12 No. 1, AugustLuthf. 8

Hadiz, V. R. (2010). Localising Power in Post-Authoritarian Indonesaia: A Southeast Asia Perspective. Stanford, CA: Stanford University Press. 
Hidayat, S. (2007). Shadow State? Business and Politics in the Province Banteng, In Schulte Nordholt H and Van Klinken G (eds) Renegotiating Boundaries: Local Politics in PostSuharto Indonesia. Leiden; KITLV Press, pp, 203-224.

Hidayat, S. (2001), Pola Hubungan Penguasa dan Pengusaha di Tingkat Lokal, Jurnal Renai. Vol 01, No )1: Percik.

Luthfi, F. (2007) The Impacts of Coal Mining on the Economy and Environment of South Kalimantan Province, Indonesia. ASEAN Economic Bulletin 25: 85-98.

Susanto. (2007) Ruler, Entrepreneur and Local Government Implementation Post Regional Head Election: Case of South Kalimantan Province; In: S. Hidayat (ed.),

Zulfam TM. (2007) A Future Resource Curce in Indonesia: He Political Economy of Natural Resources, \&onflct and Development. Qoeen Elizabeth House, University of Oxford 